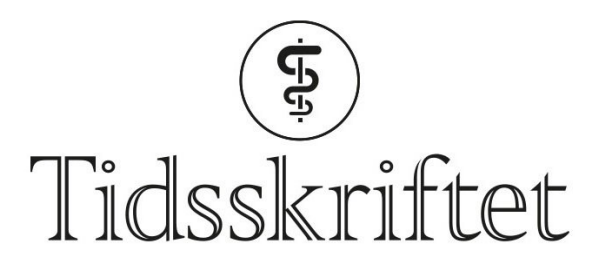

DEN NORSKE LEGEFORENING

\title{
E. Ulvestad og L. Slørdal svarer
}

KOMMENTAR

\section{ELLING ULVESTAD}

E-post: elling.ulvestad@helse-bergen.no

Elling Ulvestad er spesialist i immunologi og transfusjonsmedisin og avdelingssjef for Mikrobiologisk avdeling, Haukeland universitetssjukehus. Han er og professor ved Klinisk institutt 2, Universitetet i Bergen.

\section{LARS SLØRDAL}

Forfatterne oppgir ingen interessekonflikter.

Vi takker Hanne Nøkleby og Geir Bukholm for kommentar til vår artikkel. De hevder at vi gir inntrykk av at norske helsemyndigheter underslo informasjon for å få folk til å vaksinere seg i 2009. For å presisere: Norske helsemyndigheters informasjonskampanje for å overtale folk til å la seg vaksinere i 2009 er ikke et tema for vår artikkel. Vår hensikt med debattartikkelen var heller ikke å kritisere norske beslutningstakere fra 2009; gjort er gjort. Vårt poeng - at alle bindinger og fakta som kan påvirke viktige beslutninger bør bekjentgjøres - er langt mer allment og framtidsrettet enn som så.

Publisert: 19. august 2019. Tidsskr Nor Legeforen. DOI: 10.4045/tidsskr.19.0444

(C) Tidsskrift for Den norske legeforening 2020. Lastet ned fra tidsskriftet.no 